\title{
Strategies of Supervision on Guaranteeing Citizenship Rights in Administrative Organizations
}

\author{
Hassan Haghighi \\ Student of law of Islamic Azad University, Khorasegan, Isfahan, Iran \\ Seyed Mohammad Sadigh Ahmadi
}

Faculty member of law department, Islamic Azad University of Khorasegan, Khorasgan, Isfahan, Iran

Doi:10.5901/mjss.2015.v6n6s6p196

\begin{abstract}
One of the dimensions of legal reforms and development in our country is considering the concept "citizenship rights". In current law, France renovated these rights. By declaration of "human rights and citizenship" in 1789, it was revitalized. In Iran law, it has no long history. Today, public organizations play important role in the life of citizens as a few social, economic, cultural and political fields of society are not regulated from the executive power and local and administrative organizations. Supervision is a basic concept of public law and based on the views in definition of this concept, we can consider it as awareness of what is occurring and an implicit comparison between what is and what should be. For supervision, different classifications are presented. These classifications have different forms in terms of type. Today, due to its extensive role, government plays the role in all aspects of life of citizens via administrative organizations. Based on the extensive presence of government in society and focusing on public power, we should think some strategies to support the citizens against government power. This support is found in the rights considered for people and citizens from administrative systems. Based on development of rights, justice orientation, support of legitimate freedom and rights are duties of government and a part of it is done via support of people against administrative organizations and presenting the public needs and services. This study is regarding the evaluation of strategies of guaranteeing citizenship rights in administrative systems as different solutions are predicted to guaranty people rights in state organizations as various legal, non-legal supports. By considering the examples of citizens' rights and their consistency with administrative rules of Iran and based on guaranty solutions to support people rights and control of administrative organizations authorities, we can say despite positive steps regarding citizenship orientation and rights fulfilling, these rules as non-consistent and misleading people don't include all examples of people rights. Administrative system of Iran requires a complete, comprehensive law.
\end{abstract}

Keywords: Supervision, Citizenship law, Administrative organizations, Administrative reference

\section{Introduction}

High value and dignity of human being in Islam religion is emphasized in the verse:" اوَّنَ

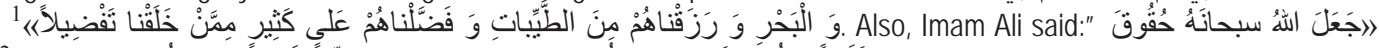

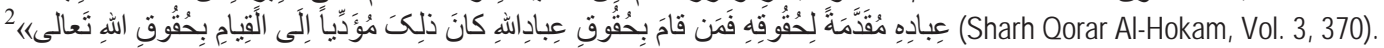

It shows the importance of this issue among our leaders. On the other hand, various principles of constitution of Islamic Republic of Iran as principles in Chapter 3 about nation rights emphasize the citizens' rights in Islamic Republic of Iran. One of the duties of government is protection of people rights and respecting legitimate freedom of citizens. Various principles of constitution emphasized on freedom and rights of citizens in various aspects of life.

Thus, to respect legitimate freedom and protection of citizenship rights, a law was approved in the form of an article by Islamic council parliament in which some duties were determined for courts, authorities of judiciary power to guarantee citizenship rights. According to section 15 of this law, the chief of legislative law determines a board to supervise the good performance of this law and all systems associated with this law are obliged to collaborate with this board. This board in case of any violation of law, besides reforming the methods and their adaptation with rules punish

1" And We have certainly honored the children of Adam and carried them on the land and sea and provided for them of the good things and preferred them over much of what We have created, with [definite] preference.

${ }^{2}$ Translation, God considered the rights of slaves prior on his rights and the one observing others rights, this leads to fulfilling the rights of God. 
those violating the law and the results are reported to the chief of judiciary power.

The main purpose of this study is evaluation of the solutions of supervision on fulfilling citizenship rights and we attempt to answer this basic question that first, what are citizenship rights and what are the legal resources of this right from which part of constitution, second how is the citizenship rights fulfilling in Iran and which activities are made in this regard. Third, we answer this question that what are various methods of supervision on performance of various systems of people regarding citizenship law?

By not taking form library resources and interview with experts in citizenship rights and documents of citizenship law, the data is collected.

\section{First Discussion: The Concepts and Definition of Citizenship Rights}

Literal meaning of right: Right has many meanings and in all of them, the literal root, proving is kept. The type of proving is different and various concepts of rights exist (Mesbah Yazdi, 2001, 20).

Except the literal meaning, the term right is used in various items as plural and singular as rights meaning social rules, wage, is the dominance of a person on another one, power to do an act (Haghighat, 2006, 128).

Right in the legal term: Right is the authority given by law to a person to do an act or omit another act. Ownership right, possession right. The term right in this meaning is used in Islamic law (Emami, 1963). It seems that in mānahnofih (subject at hand), right is the priority of a person in society based on law, common law, contract or religion and others should observe it (Sabet Saeedi, 2007).

The separation between two concepts of "Being-based" and "obliged based" of right is necessary in its analysis. "Being-based" concept delegate's right to non-norm based fields of philosophy as metaphysics. This concept of "obligedbased" refers right to norm-based fields of philosophy as ethics, politics philosophy and law. Religious issues are regarding the being-based rights to mystics and norm-based rights to Sharia and ethics. The separation between these two concepts is not discussed at first but review of literature and phenomenological roots of discourse against human rights show that most of disagreements are based on lack of separation between these two concepts. Descriptive right with to be right and normative right with to have right. This separation considers a deep link with separation of concepts of "value/good" and "good and right". It seems that the main idea of liberalism in social ethics and human rights is the separation of these two concepts. The idea of right to be wrong indicates importance of two concepts of descriptive right and normative right. The basis of morality as patience and ignorance in separation of these two concepts is based on right.

Some law experts consider the aim of rights in legal though as restoring order in society and legal rules are those guaranteed by competent forces of government and the aim is restoring peace and order in society. The followers of other schools considering a subjective basis for rights better than will of government consider the aim of rights as justice. According to them, the most important source or rights is view of scientists and in the views as the main source of rights and common law, the aim of rights is progress of civilization and culture of nations.

\section{Second Section: Citizenship Definition}

According to Dehkhoda dictionary, city means the gathering of many houses in which people as bigger than village but the term citizen was at first Shahrband. "Vand" means a person who is restricted in a place. According to Marshal, citizenship is a basis given to all people as the member of society. These people have equal position, rights, and duties in accordance to this basis (Friedman, 2002).

Indeed, citizen is the one living in city or country enjoying the relevant rights. According to Antony Giddens, citizen is the member of a political society with some rights in this membership. He considers civil rights as legal rights of all citizens (Giddens, 1988, 795).

Thus, citizenship rights are a set of duties of citizens to each other, city and government with the duty of providing the duties and by resorting to it, citizens expect to achieve all their rights as constitution, employment right, selection right and being selection, certificate right in formal courts, assessment right.

Real law manifests right, development of cultural fields, respecting law, a step taken to develop citizenship rights that citizens learn the law merely is holy as guarantees their rights and providing public benefits. 


\section{Third Discussion}

\subsection{First section: History of supervision}

The term "supervision" is raised by various methods in various governments. In Akhamanid era and kingdom of Cyrus and Darius, supervision was administrative job (Pirnia, 2010, 462).

After the advent of Islam, supervision was a tradition of fixed divine traditions. Exact supervision of intentions of people and evaluation of human acts in dooms day is a concept indicating this issue. Ignoring the moral discussion of supervision, this concept in government structure has special position in practical trend of the Prophet (pbuh) and Imam Ali.

The method of the Prophet (pbuh) was as whenever a commander was determined on the troop, as they were sent to a mission. Some trusted people were appointed to supervise his performance and report for them.

The supervision and inspection in government and management of Imam Ali as a complete model of Islamic government is one of the items as considered by him frequently (Amid Zanjani, 2010, 21).

\subsection{Second section: Different types of supervision}

Supervision is classified from various aspects. One of them is dividing supervision into two general aspects of "government supervision" and "people supervision". Government supervision is divided into various forms as organizational supervision (hierarchy and guardianship supervision), qualitative supervision (legal, administrative, financial, political and parliament), internal and external supervision, shape supervision (continuous and case), previous and next supervision and trend-based, intrinsic supervision (approbation and notification), etc. and divided people supervision into public opinion, freedom of parties, society, freedom of press, media, etc. (Amid Zanjani, 2010, 24).

A. People supervision: Public supervision as considered as social capital is based on public or general to achieve public participation to achieve supervision goals (Asghari, 1999, 29).

B. Political supervision: Political supervision is the study and investigation by political authorities of country on governments and their property to be sure of their good performance (Amid Zanjani, 2010, 53).

C. Legal supervision: Legal supervision is the one applied by judiciary power and is one of legal principles in most of legal systems in the world. This term is specifically regarding supervision of legal institution on executive authorities' decisions and government powers (Bahadori, 2010, 32).

Administrative supervision as called hierarchy supervision is the one in administrative system of country and is applied by this system. This supervision in terms of supervisory hierarchy is a complementation to political supervision as from state organizations or local organizations (Amid Zanjani, 2010, 131).

D. Financial supervision: Financial supervision means the supervision on all possessions of state systems and all institutions applying state budget (Amid Zanjani, 2010, 197).

\subsubsection{Legal supervision}

Legal supervision is the investigation of the consistency of acts of institutes with rules by authorities with the aim of legalization of all affairs of government and achieving law governance (Amid Zanjani, 2010, 231). This type of supervision includes all mentioned items but it is a part of this supervision not being under different types of supervision. Some people has divided supervision into approbation and notification. Notification supervision is the one in which legal acts are performed with the supervisor and he is notified of the process but cannot interfere in decisions. In approbation supervision, legal acts are done by authorities and are under the direct supervision of supervisor. The supervision is divided into internal and external. Internal supervision is the supervision of human being on self, thoughts and acts and is based on self but external supervision is the one applied by a person or organization on acts of person or other organizations (Javan Araste, 2009, 182).

\section{Fourth Discussion: Supervision and Guaranty of Citizenship Rights}

\subsection{First section: Parliament supervision}

Parliament is the first agent of people in supervision on affairs of government. One of the solutions to protect the rights of citizens against administrative and executive systems in various countries, parliament supervision on administrative 
systems in various forms is for avoiding the violation of government institutes namely executive systems namely people freedom and rights. In constitution of Islamic Republic of Iran, supporting the freedom and rights of people in administrative, executive, principal systems is dedicated to supervision of Islamic council parliament on these systems. Here, supervision of parliament on administrative systems regarding citizenship rights is investigated. This supervision is raised in legal and political supervision.

a. Legal supervision

1- Supervision of parliament on administrative decisions based on 85 and 138 articles of constitution

2- In the final part of article 85 of constitution, ........", the government approvals shall not be against the laws and other general rules of the country and, while calling for implementation, the same shall be brought to the knowledge of the Speaker of the Islamic Consultative Assembly. This type of supervision is separated from president supervision on state rules as predicting specific power for the Speaker of the Islamic Consultative Assembly to supervise on the approvals of government (Ostovar Sangari, 2012, 87).

According to article 138 of constitution "In addition to instances in which the Council of Ministers or a single minister is authorized to frame procedures for the implementation of laws, the Council of Ministers has the right to lay down rules, regulations, and procedures for performing its administrative duties, ensuring the implementation of laws, and setting up administrative bodies. Each of the ministers also has the right to frame regulations and issue circular in matters within his jurisdiction and in conformity with the decisions of the Council of Ministers. However, the content of all such regulations must not violate the letter or the spirit of the law. The government can entrust any portion of its task to the commissions composed of some ministers. The decisions of such commissions within the rules will be binding after the endorsement of the President.

Thus, those approvals inconsistent with the rights of people in regulations, according to 138 article should be revised and Speaker of Assembly has the authority to avoid the ratification of administrative rules despite people rights in executive systems.

The problem is that in legal system, there is no supervision before making state rules and relevant institutes apply their supervision after making rules.

b. Political supervision

1- Notification supervision of assembly on administrative and executive systems based on article 90:

According to article 90 of constitution: "Whoever has a complaint concerning the work of the Assembly or the executive power, or the judicial power can forward his complaint in writing to the Assembly. The Assembly must investigate his complaint and give a satisfactory reply. In cases where the complaint relates to the executive or the judiciary, the Assembly must demand proper investigation in the matter and an adequate explanation from them, and announce the results within a reasonable time. In cases where the subject of the complaint is of public interest, the reply must be made public.

Based on this article, assembly as the center of lawyers of nation and the closest institute as formed by will of people. People should refer to their representatives for their problems. Besides complaints of people to judicial power, by notification of representatives, people can achieve their rights and this is a spiritual good performance to achieve the rights. We can say that at first people complain to these courts and if they didn't achieve any result, they can complain the parliament. This type of complaint is a political one against frequent violations of public systems (Hashemi, 2014, 163).

Based on this article, there is a right for citizens that in case of any complaint to administrative and executive systems, they can present their complaints to the commission "article 90 constitution of commission" as established for this reason.

According to the law of direct research and correspondence to article 90 commission with state systems to people complaints approved on Jan 21, 1981 article 90 commission, they can refer to three powers of Islamic Republic of Iran and all ministries and affiliated organizations and revolution institutions as relevant with one of the mentioned powers and get reports to deal with written complaints as not replied or without any satisfactory answer and they should reply immediately".

According to additional note of article approved on Dec 23,1985 , the mentioned authorities in the article can write and research directly to article 90 commission with state systems to deal with the people complaints approved on Jan 21, 1981 of Islamic consultative assembly and notify their reply at most within one month of receiving to article 90 commission. Violation of this law is crime and the offender is punished to imprisonment from 3 months to one year and resignation of state services from 6 months to one year and the offense is dealt in court with the request of commission and they should deal with these crimes as urgent and after proving the crime and punishment notify the mentioned commission.

In addition, the law of article 90 of constitution of Islamic Republic of Iran is based on 9 articles and five notes and 
it was approved on May 15, 1986 by Islamic assembly and it was verified by Guardian Council on Nov 26, 1986. Article 2 of this law states that:

Besides the explicated power in article approved on Jan 21, 1981 and its additional note on April 25, 1985, this commission can invite or correspond with the authorities directly and they should accept, otherwise, by proving lack of reply by commission, the court should deal with it as urgent and in case of proving the crime, punishment is determined in the article note and the result is reported to commission and in this case, the court dealing with crime of no replay cannot deal with the original complaint in commission.

The investigation of complaint in assembly is different in various powers and this is regarding the institution with parliament nature. The result of parliament performance despite judiciary power leading to the issuing of verdict or executive power leading to issuing regulation to eliminate the problem, it leads to public notification and can be guidancebased (Hashemi, 2014). This cannot bring important result to fulfill citizens' rights due to lack of good performance.

\subsection{The right of investigation of Islamic Consultative Assembly in administrative systems based on article 76 of constitution}

According to article 76 of constitution: The Islamic Consultative Assembly has the right to investigate and examine all the affairs of the country.

As assembly is the symbol of public management, it should research and evaluate the affairs and all government institutions as they deal with freedom and rights of people to avoid government acts deviation. Constitution considers extensive power for assembly and by mentioning all matters in materialistic concept, all internal and international issues and in organizational concepts, all organizations and authorities are included in the above supervision principle (Hashemi, 2006, 173).

It seems that exception of research and evaluation from council of guardians, The Expediency Discernment Council of the System, judicial courts and affiliated leadership systems, without presenting alternative supervision solution in article 198 is regulation of violation of citizenship law. These institutions are in contact with people in their duties and the result of performance is effective on various rights and aspects of life.

According to article 198 of internal regulations of parliament and relevant notes, research and investigation request from representatives is referred to specialized commission and the research institution is obliged to present all documents and information of commission for investigation.

According to article 76, the Islamic Consultative Assembly can investigate and examine all affairs in country and if there is any violation in rights of people, it is referred to relevant judicial court.

\subsection{Second section: Administrative supervision}

\subsubsection{Supervision based on performance management system}

Based on management law of country services of executive systems as ministries, organizations, institutes and state companies as queue and staff units from the law maker are created to do state duties and based on duties, responsibilities and resources of each of mentioned units can respond. The performance evaluation is one of the most important strategic processes and besides improving responsiveness, fulfillment of goals and plans of organization are defined. Evaluation is one of the key activities and main elements of management and it is an efficient tool by which manager and employees can find about the strengths and weaknesses of organization and perform modifications to improve the performance.

According to article 36 of management law of country services, "Executive systems are obliged to perform processes and methods of good work with the aim of increasing productivity of human resources and efficiency of activities as speed, accuracy, quality costs, health and validity of affairs and satisfaction, people dignity and these methods are revised every 3 years at most.

Note- The productivity and efficiency of activities, people satisfaction of state services, based on the indices verified with the executive systems are measured annually by organization with the collaboration of relevant systems and the results are included in the evaluation of their performance". According to article 81 , executive systems are obliged that based on the regulation approved by board of ministers with the proposing of organization establish performance management system and perform productivity in their units and provide periodical reports and report the results to organization. According to article 82 , the organization is obliged to establish performance management system in all executive systems and present a report of the performance of executive systems and their assessment in private and 
public indices and the performance of orders of this law based on regulation approved by board of ministers in session dated on Jan 8, 2003 based on the proposal of planning and management organization of country " regulations of evaluation of the performance of executive systems". Article 3 of this code evaluates citizenship as one of the public dimensions of executive systems performance as evaluated.

Based on citizenship index, the recognition of needs and assurance of consistency of quality of services with needs and expectations of citizens are duties of administrative systems and are considered in performance evaluation. Thus, using the results of survey of citizens' satisfaction of executive systems in formulation of performance report can be considered.

Thus, the satisfaction of people and observing their rights by executive systems including service management law was effective on their performance evaluation and the performance of these systems was controlled by planning and management organization of country (deputy of development and human capital management of presidency) and finally in a report to president and Islamic consultative assembly can be presented. According to article 7 of this code, the results of performance assessment are improving responsiveness and clarity of executive systems and awareness of people of condition of performance of systems and increasing general trust.

\subsubsection{Investigation of complaints of people by executive systems}

The necessity of establishing feedback system of views and complaints of citizens as one of the basic needs of successful organizations as:

- A suitable method to measure the organization performance.

- A useful method to promote the qualification of organization and effective methods to achieve improvement of services.

- A good tool to avoid deviations of organization performance to present services to people.

- A good criterion to be sure of proper performance of improvement, evolution and development of organization and organization capability is increased to improve services production.

Thus, high administrative council in session on July 26, 2005 based on common proposition of complaint investigation center of presidency and planning and management organization of country and improving responsiveness of executive systems approved the regulation of responding to complaints of people from executive systems.

According to article 2 of regulation, the goals of creating the system of complaints investigation is as followings:

- Improving responsiveness of executive systems to people

- Increasing satisfaction of people of public services

- Improvement and development of standards of services

- Policy making to reduce dissatisfaction via documentation, classification and prioritization of complaints

- Analysis and revision of efficiency of rules and executive regulations in executive systems

According to article 3 of this regulation, responding to complaints of people is in four levels of town, province, system and national level as shown in regulation.

According to the sections in article 90 of country services...." Any ignorance to the affairs and violation of public rules can be forbidden. The client can complain in case of bad behavior of employees and ignoring the duties to relevant executive systems or legal courts.

Based on recent section of article 90 of management law of country services based on the regulation of evaluation of performance of executive systems " approvals of board of ministers " and regulation of responding management to complaints of people from executive systems, in offices, some units are formed as "evaluation of performance and responding to complaint.

Thus, in case of any ignorance in affairs and violating their rights, citizens can refer to the performance evaluation unit and complaints of administrative system.

\subsubsection{Investigation of complaints of people by private administrative courts}

According to article 97 of management law of country services (dealing with the items as forbidden in this law and other violations of employees of executive systems and their punishment are based on the law of dealing with administrative violations approved in 1993,...).

Article 7 of dealing with administrative violations in the definition of litigant, he is legal or real entity as attributed the violations to employees and the issue is sent as written to the board of employees.

Based on this article, one of the items is dealing of boards to administrative violations, it is personal complaint and 
client.

In addition, in case of any complaint not included in the law and in contradiction with their benefits, citizens can refer to other places and in other rules, investigation of citizens is referred to another organization.

One of the boards of tax resolution in tax systems and commission of article 77 of municipality and board of high council and supervision of real estate organization.

The votes from these institutes can be revised in Court of Administrative Justice.

\subsection{Third section-Judiciary supervision}

Judiciary supervision is divided into general and private judiciary supervision. The difference of these two types is in their direction. Public supervision is based on proper execution of rules in administrative systems and topic of supervision is investigation, decision and measurements of executive units.

Direction of general supervision is punishment and direction of private supervision is cancellation (Rasekh, 2011, 1090).

\subsubsection{Judiciary supervision on administrative systems by inspection organization of country}

According to article 174 of constitution" In accordance with the right of the judiciary to supervise the proper conducting of affairs and the correct implementation of laws by the administrative organs of the government, an organization I will be constituted under the supervision of the head of the judiciary branch to be known as the National General Inspectorate. The powers and duties of this organization will be determined by law.

Although National General Inspectorate is under the supervision of judiciary branch, the supervision of this organization is administrative one. According to the law of National General Inspectorate, approved on Oct 11, 1981 and revision law July 28, 1998 and revision law on Oct 7, 2014, continuous inspection of all ministries and offices and security forces and state companies and institutions and municipalities and revolutionary institutions and organizations in which total or part of capital or stock are dedicate to government or the government supervises it, all the organizations as their inclusion (their name based on regular plan) is on the organization (section a, article 2).

Inspections of organization are performed in three forms:

1- Continuous inspections in which organization as independently with regular plan, at least once a year send some boards to ministries, offices, companies and institutions in responsibility of organization. One of the strengths of this law in accordance to article 26 of inspection law is using inspection board of various classes of people, namely worker and deprived class. It seems that the deprived classes, namely the villagers are under the oppression of administrative system due to the lack of reading and writing and they can fulfill their rights and this prediction is proper.

2- Urgent inspections with the request of the head of the judiciary branch or request of (commission of article 90 of constitution of Islamic consultative assembly) or with the request of minister or expert of relevant systems or any other case as necessary based on the view of the head of judiciary power.

3- Case inspections as performed following the complaints of people or their notifications. Thus, the acts of administrative systems are reviewed by the National General Inspectorate and in case of any violation (ignoring the rights and affairs of citizens), it is reported to judiciary branch or administrative and discipline branches.

One of the concerns of constitution in establishment of National General Inspectorate was guarantying rights and freedom of people and constitution predicted formal institutions as council of guardians, Court of Administrative Justice, article 90 of constitution and National General Inspectorate ${ }^{3}$. In National General Inspectorate, people can complain in case of any violation to their rights and freedom against administrative systems or public authorities to this organization. According to section c, article 1 of National General Inspectorate, one of the duties of this organization is investigation of the complaints of people and article 9 of regulation states that:

Any person can deliver its complaint against the organizations and institutions in article 2 of law of National General Inspectorate and their employees directly to the organization. Based on article 2 of National General Inspectorate formation, all state and public institutions are mentioned and people can complain of all mentioned institutions and it is a basic guarantee to support them (Rezazade, 272).

It seems that the organization couldn't have good interaction with the non-state organizations to supervise

${ }^{3}$ Detailed negotiations of Islamic consultative assembly, Period 4, Session 426 
citizenship rights.

\subsubsection{High board of supervision on administrative offenses}

According to article 22 of law of investigation of administrative offences, high board of supervision to supervise good performance of administrative offenses law in systems can be formed. In case of observing some items from each of initial boards or revision board, as lack of observing law of dealing with administrative offences and similar rules or discriminative performance of rules can cancel their decisions. Also, high board of supervision can send inspectors to the relevant systems and in case of any violation, offender employees can be introduced to boards of investigation of administrative offences. Judiciary power by presence in high board of supervision on administrative offences on good performance of administrative offences can manage the members (Rasekh, 2009). One of the basic forms in this type of supervision is lack of non-state members (e.g. agent of employees), in initial, revision and high council board and these boards try to emphasize on benefits of government and state organizations than protection of the rights of citizens and employees of government.

\subsubsection{Private judiciary supervision}

\subsubsection{Judiciary supervision on administrative systems via Court of Administrative Justice}

The nature of power is the main element of autonomy of public law. In the relations between government and private people, the power is explained by the privileges as not recognized in general rules (private law).

The management can be by one-way acts with the validity of the decision and is enforced sometimes by public power. In administrative contracts, the performance of his commitments depends upon his request.

We cannot resort to state power against government as public power is available to it. Thus, we should observe law rules as this action of government should be based on legal rule. His qualifications should be exactly in accordance to the legal rule. It should be accepted that executive power can formulate regulation, code and required instructions to implement the rules and administrative rules can be used via the officers.

There should be a guaranty that government acts beyond law or legal rules and private people by courts can apply required good performance (Shams, 2002, 132).

One of the guarantees is legal guaranty, referring to judge to state the illegality of decision about complaint.

The judge should investigate the legality or illegality of decisions and his decision based on judgment has the validity of judged affair. The one being ruled is obliged to refer to judgment courts. In France, to investigate the claims against public institutions of country and government, some centers are predicted as different from judiciary centers and specific rules investigate the issues. In Iran, this is the responsibility of Court of Administrative Justice.

Administrative organs in Iran are based on France law and state council of mentioned country in the law of state council in 1960 approved by national council and Senate council. This law was not implemented but in article 172 of Islamic Republic of Iran constitution, a reference order as Court of Administrative Justice was issued and based of the first law of Court of Administrative Justice was approved on Bahman 1981 (Ibid, p. 134).

The new law of Court of Administrative Justice was approved by the Expediency Discernment Council of the System since Dec 13, 2011 or new revisions on June 15, 2013.

\subsubsection{The position of Court of Administrative Justice in judiciary system of country}

Court of Administrative Justice is one of the mechanisms of support and protection of citizenship law in constitution and this institution has high services compared to other institutions as associated with citizenship rights and people. The history of formation and revisions in structure and its powers show that this court has special position.

According to article 173 of constitution, In order to investigate the complaints, grievances, and objections of the people with respect to government officials, organs, and statutes, a court will be established to be known as the Court of Administrative Justice under the supervision of the head of the judiciary branch. The jurisdiction, powers, and mode of operation of this court will be laid down by law.

According to article 173, Court of Administrative Justice is under the supervision of the head of the judiciary branch. Thus, like public courts of judiciary, Court of Administrative Justice is a judicial court but qualification of court to public courts of judiciary is legal reference with specific qualification and only deals with the claims as in its specific qualification in accordance to law. 
Although compared to judiciary courts, Court of Administrative Justice has specific qualification but the court itself has public qualification against specific administrative courts or according to some authorities of specific administrative court. These specific courts only investigate some of the arguments between people and government as tax commissions or courts of resolution of worker and employer, etc. but the court is responsible to investigate the complaints of people from state units and their officers. In addition, specific administrative courts are subordinate courts to the court as the court is the highest administrative legal court in Iran and the verdicts given by these specific centers are investigated as form-based in justice court and reference court can cancel or verify the definite votes of the reference. Also, court of justice is one of the branches of judiciary power but these administrative organs belong to executive power (Rezayizade, 2006, 245).

\subsubsection{The qualification and authorities of the court of administrative justice to support citizen rights against administrative organs}

Authorities of court in dealing with complaints of citizens against government are mentioned in sections 1, 2 of article 13 of court of justice approved in 2013.

Thus, legal qualification of court to support people rights against state systems can be divided as followings:

\subsubsection{Legal supervision on decisions and measurements of government in executive and administrative affairs}

According to section 1, article 13 of the court of administrative justice, investigation of complaints and objects of state people as ministries and organizations and state companies and municipalities and revolutionary institutions and affiliated institutions and decisions of mentioned units in affairs of their duty are the qualifications of the court of administrative justice.

Based on article 173 of constitution and article 13 of the court of administrative justice and other rules on philosophy of establishment of main rights of legal supervision on government acts, first the plaintiff in this legal court is people and investigation of claims of state units against each other or legal or real entities of private law are outside of their qualification. Second defendant is state units in state law and officers, third, court is mostly the court of investigation to the claims of public law and authorities and people arguments with state units in the domain of private law are the duties of public judicial courts.

The investigation of the court of administrative justice in these cases is by nature and if the court determines the complaint as right, the decision is cancelled and the defendant is obliged to legal duties. Thus, determining the damages of action or omission of act of defendant after the verification of court in note 1 of article 13 is based on public court.

\subsubsection{Legal supervision on decisions of votes of quasi-judiciary courts}

Although investigation of absolute disagreements and claims are specific duties of judiciary power, the law maker considers the reference of specific administrative court in dealing with some of arguments and legal supervision on their deterministic decisions is delegated to the court of administrative justice. According to section 2, article 13, investigation of complaints of votes and deterministic decisions of administrative courts, inspection boards, commission as tax commission, workshop council, worker and employer resolution board, commission of article 100 of Municipality law and further reforms in terms of violation of rules or disagreement with them are the responsibilities of court.

Thus, in case of violation of offices to their freedom, and in sections 1, 2 of article 13, citizens can refer their complaint to administrative justice and administrative institutions in case of violation to materialistic law of people have civil liability and in case of violating the freedom of people have penal liability (Hashemi, Seyed Mohammad, 2003, 29).

The court of administrative justice as general court of dealing with administrative claims is the supporter of people rights in administrative systems.

\subsection{Fifth section: The barriers of goals of court in protection of citizens' rights}

The main goal of the court of administrative justice is control of governance acts and control of power to support people rights. One of the solutions to achieve this goal is fulfillment of law governance and responsiveness of authorities. The interpretation of council of guardians of article 170 of constitution without considering article 173 and limitations with the implementation of rules for intrinsic qualification of court by parliament shows that applying some parts of governance is out of the control of the court of administrative justice (Note of article 12, court law) and this approved law is used to 
violate the rights of citizens as in accordance to article 9 of constitution, no authority has the right to abrogate legitimate freedoms, not even by

Enacting laws and regulations for that purpose, under the pretext of preserving the

Independence and territorial integrity of the country. The interpretation should be wise and based on goals of constitution and reference law and descriptive interpretation without presenting alternative solution of control and supervision , people rights are ignored and despite these legal limitations, if each of institutions take false decisions and damage people rights, we don't know which legal court deals with complaint (Ramezanpour, 2009, 18). The investigations of court namely in pubic board and some branches to some decisions despite the law of legal institutions emphasize on the fact that this legal institution can have effective role in implementation of law governance and responding the authorities. The lack of province and town branches is other barrier of court to protect citizenship rights.

Establishment of provincial administrative offices reduces administrative problems but litigation limitations still remain. The lack of good relationship between quasi- judiciary courts and elimination of decisions of some of quasijudiciary courts outside of the qualification of court are other barriers.

\section{Discussion and Conclusion}

Finally, supervision is a highly applied concept in public law and based on the views in definition of this concept, we can consider it as awareness of what is occurring and an implicit comparison between what is and what should be. For supervision, different classifications are presented. These classifications have different forms in terms of type. From subject view, we can view supervision and divide it into political, administrative, legal, financial supervisions. In terms of supervision execution, we can divide it into tacit and explicit or in terms of role of supervisor, we can divide it into approbation and notification. Supervision has basis in Islamic jurisprudence. Fulfillment of monotheism and Sharia, protection of property and life of people against transgression, revitalization of right and justice and riot against wrong and grievance, caution in important matters, fulfilling virtue and avoiding vice and make efforts in Muslims affairs, protection of public benefits are the jurisprudence basics of supervision. For legal basics, we can refer to some items as lack of purity and mistake, reform and corruption elimination, increase of political participation of citizens, fulfillment of government affairs and increase of its efficiency and control of political power. Islamic Republic of Iran besides giving importance to supervision, considered many supervision methods to fulfill a part of existing supervisions and repetition of supervision, methods and responsible institutions emphasize on the significance of study.

Due to its extensive role, government plays its role in administrative organizations in all aspects of life. Based on the extensive presence of government in society and public power, some solutions should be taken to support citizens against government power. This support is found in the rights considered for people and citizens from administrative systems. Based on development of rights, justice orientation, support of legitimate freedom and rights are duties of government and a part of it is done via support of people against administrative organizations and presenting the public needs and services.

This study is regarding the evaluation of strategies of guaranteeing citizenship rights in administrative systems as different solutions are predicted to guaranty people rights in state organizations as various legal, non-legal supports. By considering the examples of citizens' rights and their consistency with administrative rules of Iran and based on guaranty solutions to support people rights and control of administrative organizations authorities, we can say despite positive steps regarding citizenship orientation and rights fulfilling, these rules as non-consistent and misleading people don't include all examples of people rights. Administrative system of Iran requires a complete, comprehensive law. As we know, administrative systems to do their duties are performed to take administrative decisions. These decisions have different types as general including all people, sometimes definite legal condition and in other times, as individual or personal. The common aspect of all administrative decisions is that citizens' rights are affected and some obligations are made for citizens and their rights are changed. Today, administrative decisions range is wide. Some solutions should be taken that in administrative decision making of organizations, the concerns of interventions and full presence of government and administrative organizations and threat of freedom of citizens via a consistent legal framework and democratic system can be eliminated. Here, formulation of general law besides taking a big step to fulfillment of governance of law and support of citizens' freedom can provide efficiency and effectiveness of organizations.

\section{Analysis}

Citizenship is one of the most important political-social fields as with various forms. Based on citizenship situation, people have equal rights and these rights are balanced with a set of commitments to government and society. 
Citizenship rights are based on civil, political and social rights and are main principles of human rights. Citizen in democratic communities is the one with nationality of country and he has some benefits and advantages as approved in constitution and other normal rules in the country. Citizenship as a modern complete social basis is a continuous set of equal public duties based on social belonging to society in public participation ignoring racial, ethnical, class, cultural and religious belonging. Citizenship rights are based on mutual social contracts and mutual rights of "government on people" and "people in government and have some barriers as a public common feeling to national and social identity. The barriers of citizenship rights in Iran are mostly based on non-explanation of position of citizenship rights, lack of citizenship rights training and lack of establishment in various social layers.

In Iran legal system, citizenship rights with a regulation on April 8, 2004 of head of judiciary power regarding observing the rights of citizens had serious form. Later, this regulation was approved as "law of respecting legitimate freedoms and citizenship rights" on May 4, 2005 in Islamic consultative assembly. Thus, the law obliged government and judiciary power to provide charter and draft of citizenship law. The formulation of such draft in Iran legal system had some barriers and challenges as lack of exact position of government and judiciary power in formation of such draft, ambiguity in the concept of rights, concept of obligation and concept of citizen.

According to article 20 of constitution, "All citizens of the country, both men and women, equally enjoy the protection of the law and enjoy all human, political, economic, social, and cultural rights, in conformity with Islamic criteria. The development of all people is provided. The term rights of nation in third chapter of constitution and specifically in this article is ambiguous like other similar terms. At first the meaning of people is based on the term nation. Based on other articles in chapter 3, the law maker considered a concept beyond people. For example, job freedom right (principle), prohibition of arresting (article 32), forbidding obligatory residing (article 33), litigation right (article 38), innocence (article 37), torture prohibition (article 38), prohibition of Aspersion of the dignity (article 39) and violating the public interest (article 40) and they are the items that cannot be restricted to Iran people. In addition, the term "human rights" in article 20 of constitution is beyond specific people rights in Iran and the first suggestion is fundamental rights as any person can enjoy it.

The judiciary is an independent power, the protector of the rights of the individual and society, responsible for the implementation of justice, and entrusted with the following duties in five sections of 156 article of constitution. Based on second section of this article, "restoring public rights and promoting justice and legitimate freedoms;" is one of the most important duties of judiciary power and it is used in section 2 of 156 article "providing legal drafts in accordance to Islamic Republic of Iran". The term "public rights" in this section of constitution has not definite concept like nation rights. On one hand, we can consider public rights based on one by one of people as all rights belonging to a person and on the other hand, we can use public rights in the meaning of collective public rights. In the latter meaning, "public rights" only includes the rights as using common legacy of human, using humanitarian aids, using healthy environment and similar cases and they feature is public use to their fulfillment. Indeed, this suggestion approaches public rights concept to the concept of unity rights or third generation of human rights. It seems that formulators of constitution by the term "restoration of public rights" believe that public rights in political system are violated before revolution and its restoration is necessary. These rights are public rights, not in similar meaning with unit rights and mostly is about the rights as civil and political rights as threatened before revolution.

Chapter 11 of the Fourth Economic Development Plan Law approved on October 7, 2004 with the development of legal affairs from article 130 to article 134 considered the duties of judiciary power in various dimensions.

In article 130 of mentioned law, judiciary power is obliged to provide and approve some drafts as section "h" of article 130 is provided and "support and promotion of citizenship rights and support of privacy of people based on article 20 of constitution of Islamic Republic of Iran" are the duties of judiciary power. In addition, in part 3, section " $z$ ", judiciary power is obliged to eliminate any ethnical and group discrimination in legal and judiciary domain.

The law maker in the article 100 of Fourth Economic Development Plan Law and in the chapter of promoting human security and social justice obliged the government to promote human rights, establish excellence growth and individual and social security in society and approve "citizenship rights charter" based on following items approved by the courts as:

a. Developing law abidance, law based public education and developing of culture of law, order and civility.

b. Preserving freedom and securing people's votes and freedom of suffrage-the right to elect and the right to be elected.

c. Guiding political and social activities toward legal processes, protecting and guaranteeing the said activities and lawful assemblages.

d. Securing freedom and security needed for development of the social organizations in the area of preservation of the rights of children and women. 
e. Propagating the unification and respectability concepts toward social groups and different ethnic groups in the national cultures.

f. Preservation and protection of the individual privacy

g. Enhancement of the feeling of social immunity in people and the society.

1- Based on the duty of government in providing citizenship law charter, providing the draft of citizenship rights by judiciary power is not logical.

2- What is the duty of judiciary power in section "h" of article 13 of Fourth Economic Development Plan Law, the draft of "promotion of citizenship rights and support of privacy of people is mentioned and in recent year, a draft is provided with the title of "support of privacy" by government, this draft is not legal as this duty is considered as done.

In response to the shortcomings, we can say:

1- The nature of charter as notified is different form legal draft as with its obligatory aspect. The charters are not implemented and they try to make norms to approve the law. Based on the long process of approving law, the law maker attempts to formulate such charter and required experiences to formulate draft and implementation of such law are provided. The law maker has raised such duty for government and judiciary power as separate.

2- Providing privacy draft by government as in framework of fourth plan, the problem is as the government has made a draft and it is not responsible to make it. Thus, it should be interpreted outside of framework in article 130. Providing the draft of support of privacy doesn't negate qualification of judiciary power in citizenship rights draft.

The basics of citizenship rights are providing security for the citizens that members of society can develop their intrinsic talents and achieve their goals. The important point is that in a legal definition of citizenship rights, government obligations and citizens' rights are defined. The most important guaranty to implement citizenship rights is the performance of authorities. If the authorities don't do their duties properly, establishment of citizenship rights is not done truly. We can say lack of obligation of authorities to law governance is the most important challenge of citizenship rights.

\section{References}

Akhavan Kazemi, Bahram. The supervision on Islamic system. Tehran. Islamic culture and thought center. 2012.

Akhavan Kazemi, Bahram. External supervision in political systems. The journal of Islamic government. No. 33.

Ostovar Sangari, Kurush, Emami, Mohammad. Administrative rights. Second Vol. Mizan edition. 2012.

Esmaili, Mohsen. Public participation. National governance and public supervision in political jurisprudence of constitution. Tehran. The office of Islamic culture edition. 2005.

Izadi, Seyed Sajad. The supervision on power in political jurisprudence. Qom. The research center of culture and Islamic thought. 2008.

Izadi, Seyed Sajad. The jurisprudence basics of supervision on power from the view of Imam Khomeini. Tehran. Oruj. 2012.

Pirnia, Hassan. Ancient history. Tehran. Rastino. 2010.

Javan Araste, Hossein. The selection of leader and supervision on him in Islamic Republic of Iran. Qom. Research center of Hoze and University. 2009.

Khorshidi, Mozhgan. The range of tools and supervisory results of Islamic council assembly. Office of legal studies of council of guardians. 2008.

Dehkhoda, Ali Akbar. Dictionary of Dehkhoda. Vol. 41. Tehran. Tehran University. Tehran. Farvardian. 1960.

Rasekh, Mohammad. Supervision and balance in constitution system. Tehran. Drak publications. 2009.

Rasekh, Mohammad. 2011. Supervision and balance in constitution system. Derak publication. Second edition. 109.

Rezayizade, Mohammad javad. Administrative rights (1). Tehran. Mizan 2006.

Abdollah, Shams. Civil procedure. Mizan publication. Spring 2002. P. 132.

Alinoghi, Amir Hossein. Supervision on elections and discerning the qualification of people. Nashr Ney. 1999.

Amid Zanjani; Abasali, et al., Supervision on government and administrative justice. Tehran. Tehran University. 2010.

Qazi, seyed Abolfazl. The principles of constitution. Tehran. Mizan. 1996.

Mosazade, Ebrahim; Amid Zanjani, Abasali. The supervision on acts of government and administrative justice. Tehran University publications. 2010.

Public supervision. Citizenship and organizational development. The second scientific and specialized conference of public supervision. 2007. Tehran. Institute of research and development of human sciences.

Hashemi, Seyed Mohammad. 2004. Constitution law of Islamic Republic of Iran. Vol. 1. Tehran. Mizan. 1.

Hashemi, Seyed Mohammad. 2014. Human rights and basic freedom. First edition. Tehran. Mizan.

Articles

Khamamizade, Farhad. The comparative investigation of supervision on ordinary rules with constitution. Legal teachings. Sciences University of Razavi. No. 12. Summer 2009. 
Zarei, Mohammad Hossein. The supervisory position of parliament and underlying principles. Assembly and research. Year 12. NO. 48. Alikhani, Ali Akbar. Supervision in Islamic Republic of Iran system. Research journal of Imam Sadegh University. NO. 23. Fall 2004.

Ghanbari, Darioush. The supervisory role or supervising duty. Trust. Jan 21, 2010.

Kazemi, Seyed Ali. The barriers and challenges of formulating the draft of citizenship law support in Iran. Legal journal of judiciary court. Year 71. NO. 58.

Hashemi, Mohammad. The supports and guarantees of human rights. Legal researches. Shahid Beheshti University. NO. 38.

Bahadori, Ali. The relations between powers in constitution of Islamic Republic of Iran. A view to control and balance of power theory. MA thesis. Law school. Imam Sadigh University. 2010.

Moharammi, Saeed. Supervision on political power in Shia. MA thesis. Political sciences. Imam Sadigh University. 1996. 